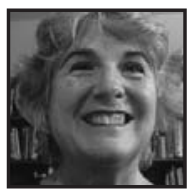

\title{
Commentary:
}

\section{Reflections on Literacy, Education and a Twenty-Year Inquiry Process}

\author{
Sandra Hollingsworth
}

\section{ABSTRACT}

In this interview Sandra Hollingsworth describes a unique experience in open-ended inquiry that lasted over 20 years. As a new professor at Berkeley she began with a study of her teaching literacy to preservice teachers from a traditional anthropologic perspective. When the study showed that her students had learned "nothing," she invited an informal group of them to share their experiences as beginning teachers learning to teach reading. The group transformed with time and became recurring occasions for all to reflect and learn about topics like social justice in urban schools, multiple literacies, race and other teaching issues. She describes some of the challenges the group encountered when trying to publish its findings and some of the key things she learned from participating in this inquiry-such as the importance of longitudinal inquiry. Finally, she introduces fellow members of the group and describes their current professional endeavours.

There is a wonderful story of inquiry in your book on "Teacher Research and Urban Literacy Education: Lessons and Conversations in a Feminist Key." I wonder if we might talk about this work. First, can you describe how your group came together, who you were and how the focus of your work came about as a result?

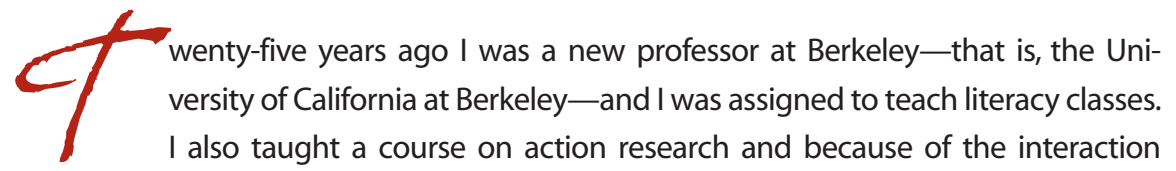


of the two I decided to study my own teaching of the literacy course through traditional qualitative methods. I hired Marsha Smith, a graduate student in anthropology, as a research assistant. During the two-semester course, she took notes on every lecture and interviewed students about what they were learning about my teaching of literacy.

At the end of the year I felt very happy; I'd thought l'd done a very good job and that those teachers-to-be had really learned a lot from me. Because I was a literacy teacher and a grade one teacher, I was very happy to share also my professional knowledge from my master's and doctoral programs on literacy. I thought I had done a very good job. So I asked Marsha to send me a paper on what she had learned. At the end of the second semester I didn't get the paper, nor did I get it during the summer. I was a little frustrated.

At the beginning of the next term I said, "Marsha, I really am anxious to read what you wrote and what you learned about this course." She said to me, "Oh Sam (that's my nickname), I just filed that in our project file cabinet before I left for the summer. I didn't think you'd really want to read it." And I said, "What"? And she said,"I don't think you're going to like it very much." And when I pulled it out and read it, I was, indeed, totally astonished, in spite of all my expertise, the reality was that my students didn't learn very much about literacy at all. After I got over my shock and put my brand-new professor hat in a drawer, I decided I'd better learn what happened. There were fifty-two students in the class and I asked for any volunteers who wanted to stay with me during their beginning years of teaching so that I could learn from them. I think at the beginning there were maybe 10 or 12 who volunteered and we met the first evening in my home. I opened the conversation by saying that I really wanted to know what happened in that class, and also I wanted to be with them while we were applying principles of literacy in their beginning teaching years.

That approach totally backfired! They didn't say anything except some perfunctory comments that were meaningless. They definitely didn't want to talk about reading. What they wanted to talk about was what they'd noticed about social injustice in their beginning year. (I'd like to add a footnote there: that became our focus, sort of, social justice in urban schools). Some of the group who were not interested in that topic left and we wound up with six of us. But I didn't know how to continue, I really didn't know how to get the information that I wanted. I had a national U.S.grant and I knew I had to report and publish on something about the beginning teachers' learning to teach, I just sat there and listened to them talk. 
Learning how to get the "real" information involved a lot of change, actually, within the group-and in every aspect of my life. I knew I still had power as a university member of the group but I had to be aware of that power and when to step back and when to allow the conversation to go where it needed to go, rather than for me to control it. I also had to develop a different style of inquiry because the traditional style was not going to work. We started where they were with the politics of schooling and then it wasn't until our second year that they really became interested in how a new teacher would teach literacy.

Will you tell us about the process over that time and some of the highlights and challenges you faced?

We had to challenge, all of us really, our thinking about traditional teacher education and the apprenticeship approach where student beginning teachers are supposed to learn what they're to do-and then apply it. Also, we had to-of course this is mainly for me-let go of the idea of methods of study that involved objectivity and generalizations. We eventually evolved into what we came to call a collaborative conversation, as both support for learning to teach and a means of studying the process of our learning. Now what I mean by that is we became-over time-a safe conversational group where we could raise problems with practice, real problems that we were experiencing, exchange ideas, challenge each other, reformulate ideas and then we all returned to our classrooms and came back the next month. We met socially at someone's home with a potluck once a month for twenty years. Over that time we began to understand the complexity of teaching for social justice in urban schools-a much broader concept than just learning to teach literacy.

Other challenges we had were how to collect and analyze the data, because that was certainly something that would have to be described if we were to write up what we were learning. We tape-recorded every conversation, had it transcribed and then collectively looked through for emerging themes and patterns ... so it took a long time. In our book you refer to, we actually went on a retreat and we all had copies of the chapters that we had written and we all commented back and forth. It was a very collaborative process on coming out with what we'd learned, and of course the learnings were very different depending on who we were in life, where we stood, our histories and backgrounds ... but it felt like an honest inquiry process.

The next challenge was publishing because major journals really didn't understand this methodology at all. We had a great deal of trouble getting published 
initially; there was, as you know, a single author, a first author, that created a big struggle for us (and publishers) to come to terms with how that would play out. It actually was a Canadian journal, "Curriculum Inquiry," that chose to publish one of our first collaborative pieces. After that, we were able to publish as a group for many, many years. Related to that, we presented at many conferences in the U.S. and Canada and in the U.K. and Australia. Many times people didn't understand the collaborative process of presenting and they would ask the teachers to sit down and for me to do the explaining because I was the "expert." In fact, when we presented the first-year results of our work to my colleagues at the University of California-Berkeley, many left the room early on because listening to teachers was not the "norm." The other aspect of the conferences was that my travel, of course, was paid for but the teachers in our group could not get released from their schools - they had to use sick leave to attend... and pay their own expenses. I started, with Karen-a graduate school research assistant and middle school teacher-and her husband Woody, a foundation to help pay some of the teachers' travel expenses.

Personally within our group, we had some major interpersonal challenges. One of the biggest was the issue of race and our own racism. We struggled with that topic from about the fourth year together. I'm not sure that any of us would ever say that we came to a final understanding of the role of race in teaching and learning, but we continue to struggle with that. Secondly, I moved to Michigan State University and didn't know how we were going to continue our monthly meetings. What the group decided to do was to tape their meetings, then mailed them to me. I had the tapes transcribed, and we continued the process from long distance.

Three years ago we stopped having our meetings because of one of our life partners - who had supported our group all of this time-died, and we all felt we had semi-finished the process. We planned on writing a final chapter together at the end our careers where we all are now. So I guess this is the final chapter!!

\section{Can you explain the most important things you've learned during this inquiry?}

In addition to the actual methodology of conversational inquiry, I learned the importance of praxis, or the relationship between thought and action, subjectivity and objectivity, theory and practice in learning to teach. The practical use of that was critical action research to achieve social justice in our teaching, including our own self-reflection and changes. The idea of praxis was so important that we did not do research on an instructional method but looked instead at the method through 
the relationship between us in our group and our outside-teachers and students in our classrooms - both of which resulted in learning to read or learning to teach reading. I changed my teaching absolutely to that approach and have had much better results over the years. The other point related to that is that I feel that the instructional perspective of practice informed by student and teacher relationships is the ultimate way to learn to teach both during pre-service and in-service education. Finally, I learned about the concept of multiple literacies, a concept that I may never have discovered without this open-ended inquiry process. We all want children and students to speak a standard school literacy, but we also want them to be appreciative of their home or community literacies and also their personal literacies which might stand in critique of both their community literacies and the standard way to read and write.

\section{Looking back now, what might you do differently?}

I struggled with that question and I talked to the group, and we couldn't come up with a thing. We talked about the importance of meeting informally, the importance of food, the importance about learning about ourselves and our teaching - but we couldn't think of anything that we would do differently.

What suggestions or advice do you have for others who might want to engage in this type of inquiry?

Jennifer Davis-Smallwood, one of our group members, wrote to me that she thinks it should be required that beginning teachers have an inquiry group during their beginning years of teaching. She called it a "caring focus group that won't let you get away with being sloppy in your teaching; you. . . have to justify your actions through student results." Fortunately now-many years after our book was published-there are many teacher-support projects. I think we are very fortunate that this has evolved into a very important way to learn to teach and also that teacher research/action research is also now very much supported as an inquiry method. We were at the beginning of those developments and we struggled for legitimacy, but now we are happy to say that those changes have occurred.

From my own perspective, I think we might want others engaged in inquiry to explore political aspects of education in inquiry. Too often, that's avoided. It's hard to talk about, just as it was hard for us to talk about race. It's hard to think in terms of power relations in schools and even in relationships impacting learning and teaching. 
I particularly would hope that we look at less critique of the methodology and more critique of the broader system and the power relationships between them. I also think it's very important for those in inquiry groups to include the researcher in the research so that there's not a standing apart but a realization that we are viewed with more expertise than the teachers even though that realization is false. We need to be open and not judgmental in the inquiry. That's the hardest lesson I have learned-to just sit and accept that people did what they did for very good reasons and try to understand why, instead of critiquing them with my predetermined beliefs, but really be nonjudgmental and open to shifts in my beliefs.

Finally, I'd like to see much more longitudinal research. Snapshots are not that informative of the real questions of learning and teaching in classrooms. It's hard to get funded for longitudinal research; in fact, we worked most of our twenty years without funding, with just a perspective that we all considered a priority in our lives and something that we wanted to do personally as well as professionally. I'd love to see more research that's longitudinal in the way that ours has been.

\section{Could you talk a little bit about the members of the group now?}

We are all at the end of our careers. We started together in 1988 and the only one of us who has really remained in a classroom is Leslie Minarik. She's always been a second-grade teacher; she's always researched her practice; she's published extensively even though she didn't get recognition from her school or her district. She's going to retire next year after 25 years and now is personally working to support children in Swaziland.

Anthony Cody was an eighth-grade science teacher in a challenging Oakland, California school when we first started. As he's moved through his career he began to work in professional development for that Oakland school district, and 24 years later he continues now to work on teacher research with a professor from Mills College in Oakland. He's gone way beyond our group to other groups. He's well known in the state of California for his work on action research and he is going to retire also next year.

Mary Dybdahl, who began as a fourth-grade teacher and then went on to become a principal at two very challenging schools in Vallejo, California, is now director of curriculum and inquiry of elementary schools in Vallejo. If anyone has done any reading about Vallejo and Vallejo schools, it is apparent that it is one of the most 
challenging place to work, but she has carried her spirit of social justice and the importance of inquiry in teaching throughout her career. She hopes within three more years that she will be retired.

Jennifer Davis-Smallwood worked as a classroom teacher, and then for many years she worked on real-life action research with kids learning in gardens and on farms - very fascinating out-of-school learning that should inform all of our work.

Karen Teel, at the time we began was a doctoral student and research assistant on a project and also taught social studies in the Richmond, California urban school district. She studied her own teaching as she was teaching African-American students, and invited an African-American partner, Jennifer Obidah, to look at her teaching and they would debrief in a similar way that we did in our group, and published a book called,"Because of the Kids,"TC Press, 2001. Later she taught Educational Psychology at the university level and directed secondary teacher education in two different universities in California. Karen and Jennifer are about to publish their third book.

I continue to teach at the university level with action research as the centre of my work. It's the centre of my teaching, it's my own personal life ... the project of social justice still is very strong with me. Beyond the stories in the book you've cited, I've collaborated with teachers and others at a challenging urban school in San Jose, California. That was very illuminating. The progress of the students was labelled so low, so I learned a new method of inquiry called "image-based research" where the children and the teachers actually use the changing image of their school within the district as an indicator of success. That work in San Jose, California along with our own work in our "Berkeley Group," I was happy to publish a book in TC Press (2000) called, "What Counts As Literacy: Challenging the School Standard," with Margaret Gallego-Leslie Minarik also had a chapter in that book.

I retired from San José State University in 2008 and I am finishing up helping with a doctoral program for school superintendants at UC-Berkeley this spring. If you think that inquiry for social justice is difficult for teachers, it's also extremely difficult for the administrators as well-there are so many political challenges to urban education. I've also been working internationally with action research through U.S. aid-sponsored literacy and assessment programs such as the "Early Grade Reading Assessment." I've been privileged to work with schools and ministries in Pakistan, Haiti, Ethiopia, Mali, Niger, British Guyana, South Africa and now in Nigeria. I too am hoping to retire in a year or two. 


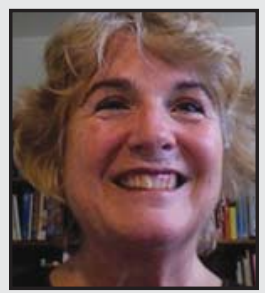

Sandra Hollingsworth is Visiting Professor at the University of California, Berkeley and a Professor Emeritus of Teacher Education at San José State University. A former published historian and K-12 classroom teacher, Dr. Hollingsworth studied teachers' understanding of the equity issues in minority students' literacy development throughout her career. She recently co-edited the American Educational Research Journal - Social and Institutional Analysis. Dr. Hollingsworth now works in developing countries to support literacy including South Asia, the Middle East, and many countries in Africa.

\section{LINK TO:}

https://www.eddataglobal.org/

https://public.me.com/samholl 